\title{
Accuracy and Reliability of Visual Shade Color Discrimination by Men and Women in Comparison to Digital Shade Selection: A Comparative Study
}

\author{
Rohit K Singh ${ }^{1}$, Prakash Nidawani ${ }^{2}$, Girish Galagali ${ }^{3}$, Satyanarayana Naik ${ }^{4}$, Srinivas Reddy ${ }^{5}$
}

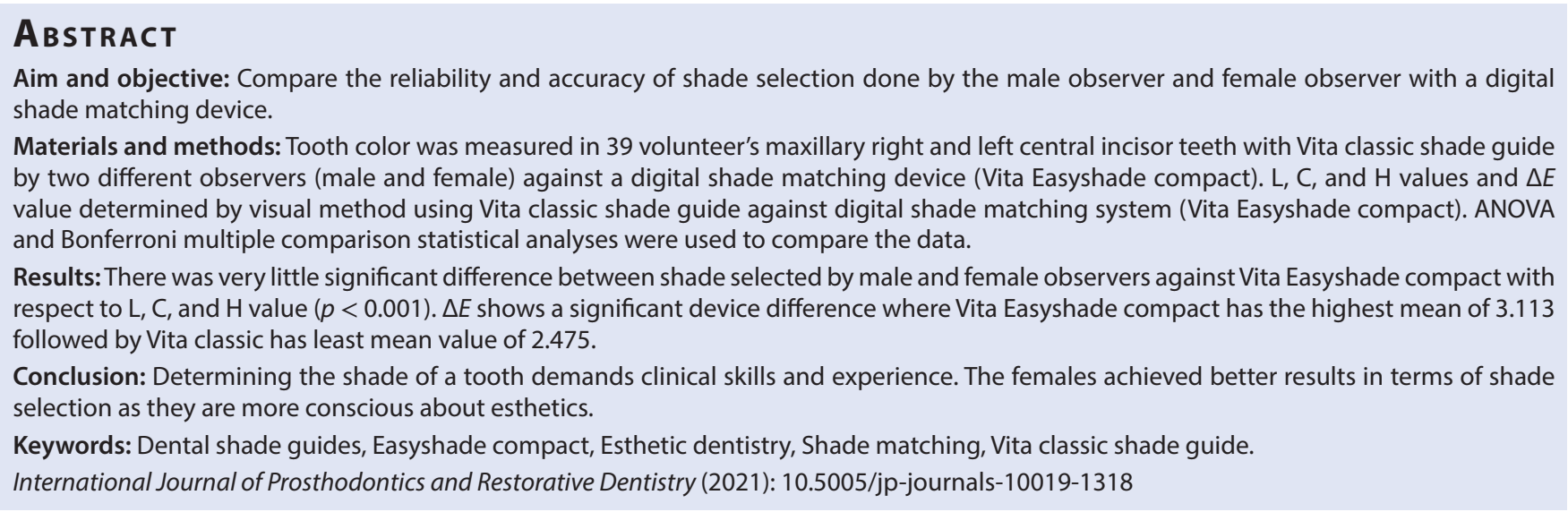

\section{INTRODUCTION}

Woody Allen once wrote a humorous essay entitled "What if the impressionists were dentists, then the whole play deals with a parody on the life of the impressionist". " Dentists are doctors of the mouth but from the last three decades, their final work is judged by the level of their artistic talents. Now, most dentists have such innate skills, and increasing the level of predictability and evidence into the subjective field of esthetic is the solution for dental clinicians today.

Esthetic consciousness in the present generation regarding color and appearance is quite significant and they are highly knowledgeable about the consequences of the same. When it comes to anterior restoration of teeth, patients are highly demanding and more possessive regarding the appearance of the restoration. Unaware in regards to the formalities of the procedure, they concentrate on the looks of the restoration and its replication to the adjacent teeth. Both shape and color of the restoration should twin with the adjacent tooth and color of the restoration being at the highest priority in judging successful and esthetically superior restoration. $^{2}$

Frequently used method for shade selection in the dental office is visual shade matching and clinicians can master the skill of shade matching through clinical experiences, knowledge, and training of shade matching protocol. ${ }^{3}$ Although many shade-matching instruments have been developed to increase the clinical success of color matching. ${ }^{4}$ One among various recent advances for the ease of shade selection is Vita Easyshade compact. This device is handheld and gives electronic optical measurements. The supremacy and accuracy of the device in analyzing and reading shade are affirmed by the manufacturers. This technology rules out the human errors observed during visual matching as it is repeatable and accurate.
1Department of Prosthodontics, Crown and Bridge, HKDET'S Dental College and Hospital, Humnabad, Bidar, Karnataka, India

${ }^{2-5}$ Department of Prosthodontics, Navodaya Dental College and Hospital, Raichur, Karnataka, India

Corresponding Author: Rohit K Singh, Department of Prosthodontics, Crown and Bridge, HKDET'S Dental College and Hospital, Humnabad, Bidar, Karnataka, India, Phone: +91 9742987218, e-mail: rks. prosthodontics@gmail.com

How to cite this article: Singh RK, Nidawani P, Galagali G, et al. Accuracy and Reliability of Visual Shade Color Discrimination by Men and Women in Comparison to Digital Shade Selection: A Comparative Study. Int J Prosthodont Restor Dent 2021;11(2):76-81.

Source of support: Nil

Conflict of interest: None

The patient's opinion should be considered as a priority while shade matching. ${ }^{5}$

This study aims to analyze the accuracy and reliability of visual tooth shade selection by men and women in comparison with digital shade systems.

\section{Materials and Methods}

The study will be conducted on the patient to evaluate the reliability and accuracy of the visual method by two different observers (male and female) using a commercially available Vita classic shade guide against a digital shade matching device. Shade matching will be done using Vitapan classic shade guide on patient maxillary anterior by two different observers (male and female). Again, on the same

(0) Jaypee Brothers Medical Publishers. 2021 Open Access This article is distributed under the terms of the Creative Commons Attribution 4.0 International License (https://creativecommons.org/licenses/by-nc/4.0/), which permits unrestricted use, distribution, and non-commercial reproduction in any medium, provided you give appropriate credit to the original author(s) and the source, provide a link to the Creative Commons license, and indicate if changes were made. The Creative Commons Public Domain Dedication waiver (http://creativecommons.org/publicdomain/zero/1.0/) applies to the data made available in this article, unless otherwise stated. 
subject shade matching is done by using a digital shade matching device (Vita Easyshade compact). The ideal site to evaluate the shade match is the middle third of the patient's tooth which is referred to as tooth's shade.

In the present study for data collection, we used Vitapan Classic Shade guide for shade selection, Rite lite for proper illumination, and Vita Easyshade compact for digital shade evaluation.

Before selecting the shade, thorough oral prophylaxis is done for the patient, sterilization of the shade guide, and collaboration of instrument carried out before using Vita Easyshade compact and the protective shield is inserted on the tips. Then, for each subject, the shade selection is done with Vitapan classic shade guide by the male and female observer and finally select the shade with Vita Easyshade compact. After collecting the data, comparison and analysis of the data of Vita classic with Vita Easyshade compact done.

Before initiating the shade matching, the participants were informed regarding the clinical procedure they are being subjected to, and written informed consent was obtained. Research has been conducted in full accordance with ethical principles, including permission from the institutional ethical committee.

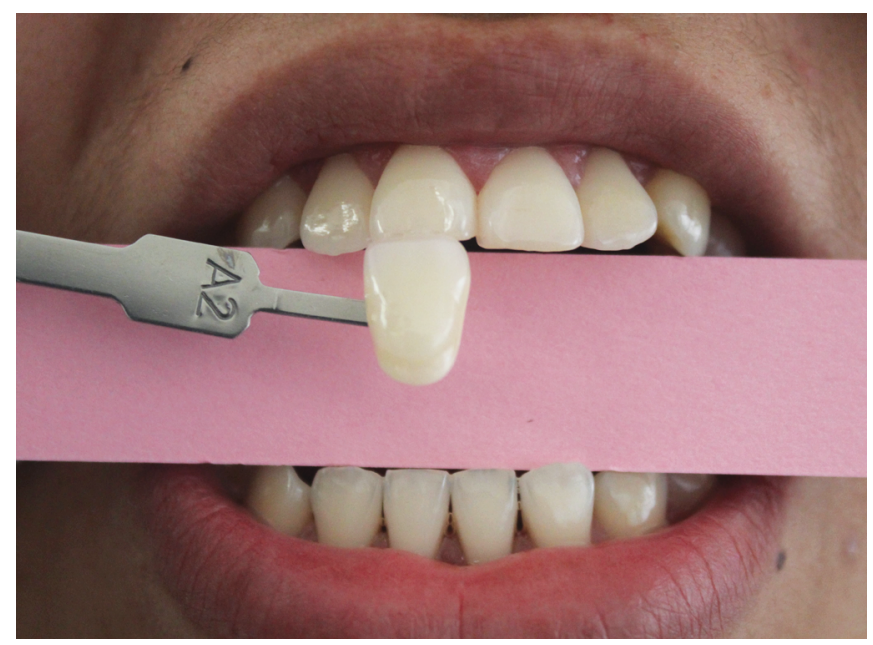

Fig. 1: Shade selected by the male observer with Vita classic shade guide

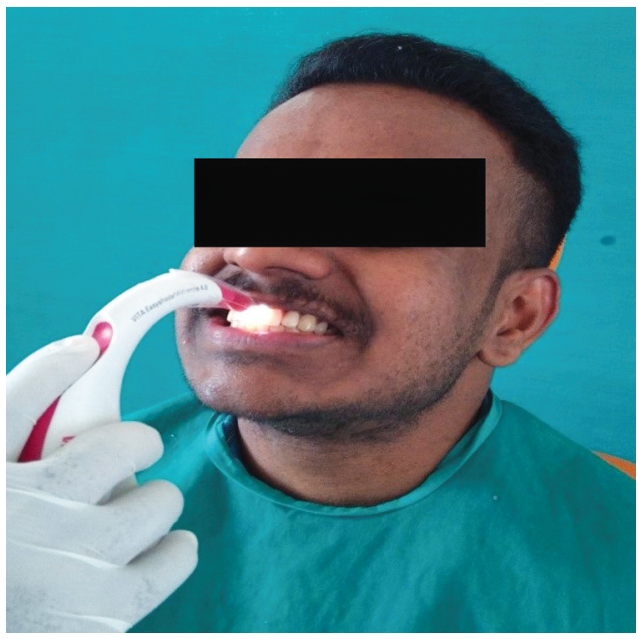

Fig. 3: Shade selection with Vita ES
Tooth color was measured in caries and fillings free maxillary anterior teeth. The total selected sample was 39. First measured tooth color with Vita classic shade guide by the male and female observer (Figs 1 and 2). Finally, tooth shade was measured with a digital method using Vita Easyshade compact (Figs 3 and 4).

Collected data were exported into the CIE $L^{*} a^{*} b^{*}$ system for the color measuring process. To measure color with Easyshade, it was was positioned and aligned correctly on the tooth (middle third of the buccal aspect of the tooth). All measurements were made by following the manufacturer's instructions. Before any measurement devices were calibrated.

The obtained data were tested for normal distribution by descriptive statistics test. Quantitative variables were compared using one-way ANOVA test. Multiple comparisons between groups were done by post hoc test (Bonferroni) test. Statistical analysis was done using the SPSS.

\section{Results}

Descriptive analysis for male and female observer for shade selected with Vita classic shade guide was presented in Table 1 (Fig. 5) and

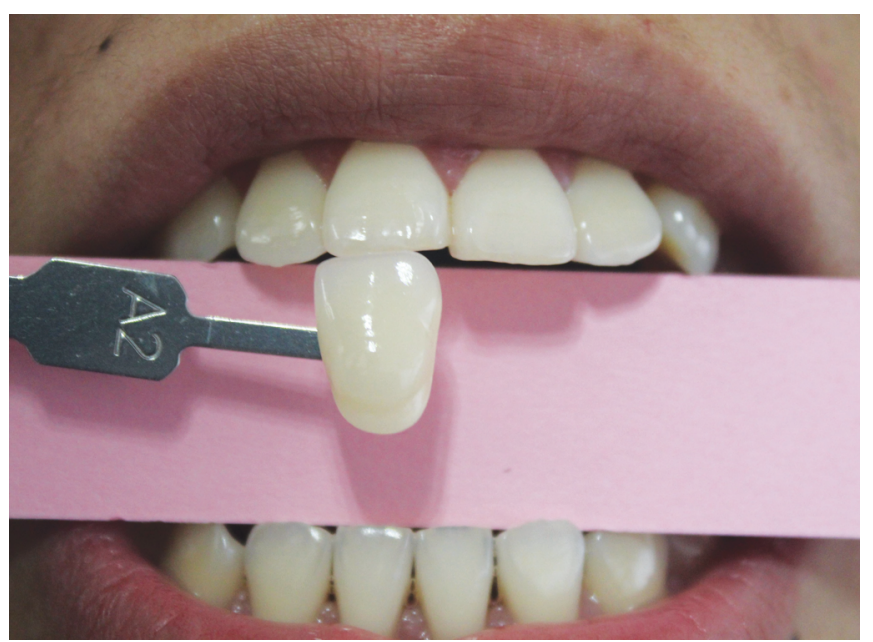

Fig. 2: Shade selected by the female observer with Vita classic shade guide

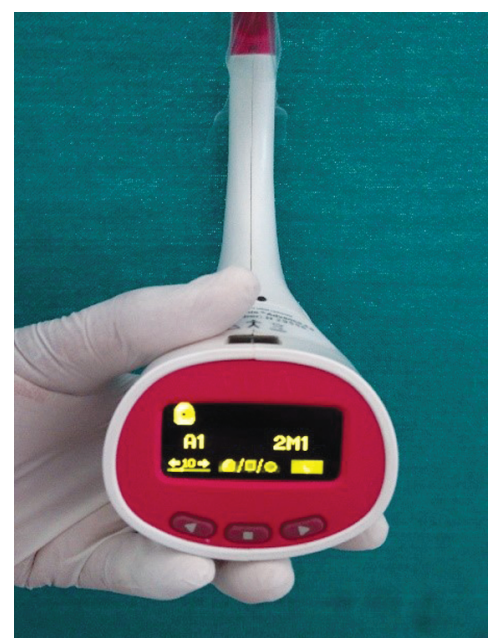

Fig. 4: Shade obtained with Vita ES 


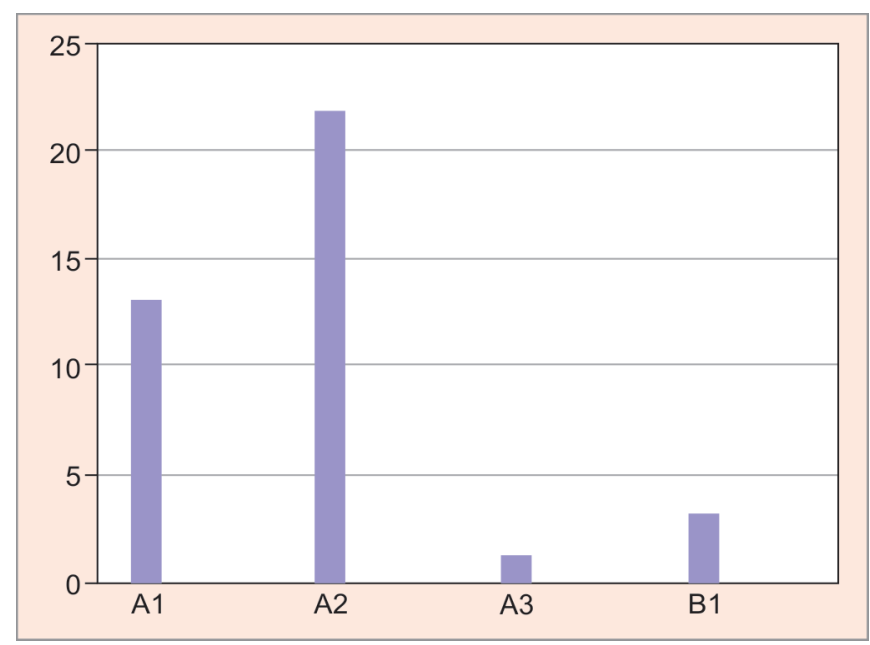

Fig. 5: Descriptive analysis for male observer for shade selected with Vita classic shade guide

Table 1: Descriptive analysis for male observer for shade selected with Vita classic shade guide

\begin{tabular}{lcc}
\hline Male observer & Frequency & Percent \\
\hline A1 & 13 & 33.33 \\
A2 & 22 & 56.41 \\
A3 & 1 & 2.56 \\
B1 & 3 & 7.69 \\
Total & 39 & 100 \\
\hline
\end{tabular}

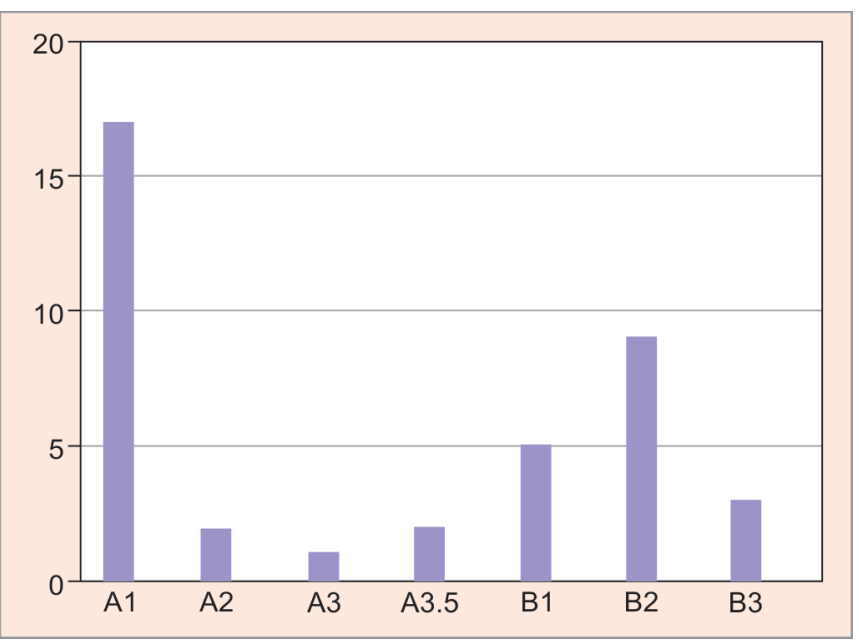

Fig. 7: Descriptive analysis for shade selected with Vita easy shade compact

Table 2 (Fig. 6) respectively. Descriptive analysis for shade selected with Vita Easyshade was presented in Table 3 (Fig. 7).

The shade selected by the male observer by Vita classic shade guide was compared with Vita Easyshade compact (Table 4) and there was a significant difference in shade selected $(p<0.005)$. The shade selected by the female observer by Vita classic shade guide was compared with Vita Easyshade compact (Table 5) and although there was a significant difference in shade selected, but difference was less $(p<0.001)$.

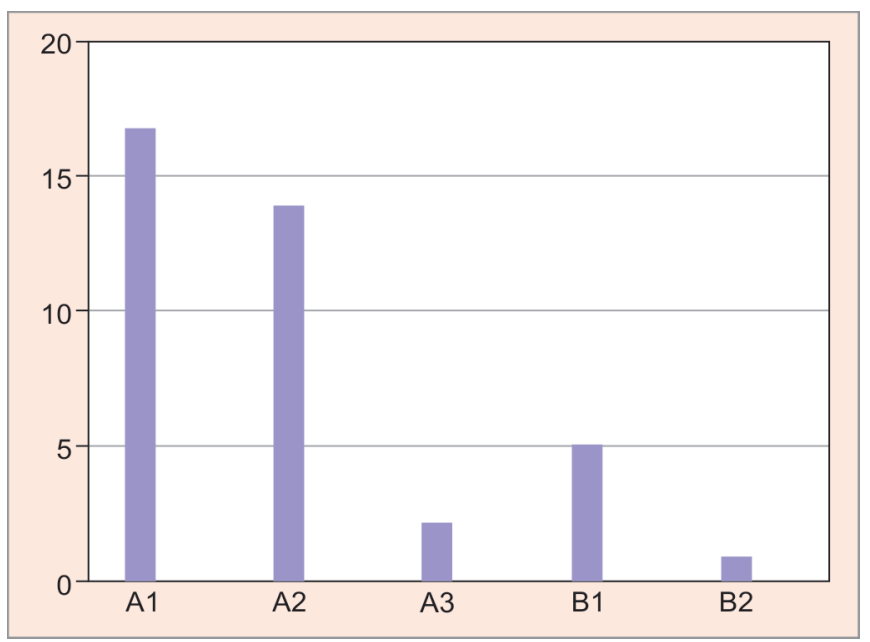

Fig. 6: Descriptive analysis for female observer for shade selected with Vita classic shade guide

Table 2: Descriptive analysis for female observer for shade selected with Vita classic shade guide

\begin{tabular}{llc}
\hline Female observer & Frequency & Percent \\
\hline A1 & 17 & 43.59 \\
A2 & 14 & 35.90 \\
A3 & 2 & 5.13 \\
B1 & 5 & 12.82 \\
B2 & 1 & 2.56 \\
Total & 39 & 100 \\
\hline
\end{tabular}

Table 3: Descriptive analysis for shade selected with Vita Easyshade compact

\begin{tabular}{llc}
\hline $\begin{array}{l}\text { Vita Easyshade } \\
\text { compact }\end{array}$ & Frequency & Percent \\
\hline A1 & 17 & 43.59 \\
A2 & 2 & 5.13 \\
A3 & 1 & 2.56 \\
A3.5 & 2 & 5.13 \\
B1 & 5 & 12.82 \\
B2 & 9 & 23.08 \\
B3 & 3 & 7.69 \\
Total & 39 & 100 \\
\hline
\end{tabular}

Finally, when the shade selected by the male observer with the female observer was compared (Table 6) a significant difference between selected shades was obtained $(p<0.001)$.

\section{Discussion}

The shade matching capabilities among women are assumed to be more evident when compared with men. Color deficiency among men is commonly seen but this fact has not affected the results of our study as all the observers enrolled were color normal. In a study done by Applebury and Hargrave, they found that in humans, two cone cell pigment genes are present on the $\mathrm{X}$ chromosome. If women are heterozygous, they could be tetrachromatic, which adds an advantage in shade matching. ${ }^{6,7}$ As there was no statistically significant difference in the quality of tooth color 
matching between color normal males and females, in the present study the null research hypotheses were accepted. Some studies reported that gender played an important role in shade matching, and females achieved significantly better results than males. ${ }^{8}$ Whereas numerous studies showed that there is no difference in shade matching ability between genders. ${ }^{9-11}$

A prospective multicenter study using five different observer groups evaluated tooth-colored restorative material in a simulated clinical setting to report the perceptibility and acceptability thresholds (PT and AT). Dental students showed PT and AT values statistically similar to the overall threshold values, which justified the selection of observers for the current study. ${ }^{12}$

Pecho et al. considered the rotation of CIELAB Color discrimination ellipsoids can play a major role in analyzing the correct shade in dentistry. The visual shade matching was done by using the Vita classic shade guide and CIEDE2000 (2:1:1) Color difference formula, which contemplates the rotation of these ellipsoids. ${ }^{13}$ When the same data were compared by gender, the shade selected by females was closer to CIELAB color ellipsoids. In the current study, also female shows more accuracy than the male observer.

A study was done by Barna et al. and they said that if dentists are having a color defect, then it will hamper the ability of shade selection. ${ }^{14}$ whereas Moser et al. tested 670 dentists at the ADA meeting in 1981 for the red-green color deficiency by using the Dvorine Pseudo-Isochromatic plate test and they found that 66 (9.9\%) men have some degree of color deficiency and 19 (2.8\%) were found to be severely color deficient. But women showed a very moderate degree of color deficiency. These studies tend to indicate that many people with color-vision defects are generally unaware of their condition. ${ }^{15}$

Normally, the human eye can differentiate between two wavelengths that are as close as $2-4 \mathrm{~nm}$. The chromatic response function is important for color differentiation as a person with normal vision can distinguish approximately 150-200 variations of Hue in the spectrum. As age increases there is a change in ability for color discrimination which may affect the ability to differentiate between blue/yellow or violet/blue-green color but the red/green color tends to remain stable. ${ }^{16}$ Rajan et al. said that the success of esthetic restoration depends on the knowledge of color science. Although limitations in materials and technique may take a perfect color match impossible, a harmonious restoration can almost always be achieved. ${ }^{17}$

For color perception within the color range of natural teeth, the brightness of the selected light source is important. Inter-Society Color Council advised using 75-100 FC of light level in a dental laboratory for proper illumination and close inspection whereas Preston et al. recommended using 200-300 fc for the dental setting. He also recommended an ideal ratio of task illumination to room illumination of 3:1. ${ }^{18}$

Barna et al. found that shade selection is not significantly affected within the range of 75-300 FC and there was an interplay between the source of light and shade guide when judgments were made, in context to values of teeth. Foot candles are important in shade selection, but so are the inherent wavelengths of the light source used. ${ }^{14}$

Sproull demonstrated that dental shade guides were not accurate, as they did not extend through the volume of color space. Most guides lack an orderly or systematic arrangement and few guides show clustering, duplications of colors in certain parts with voids in other applicable color space regions. This

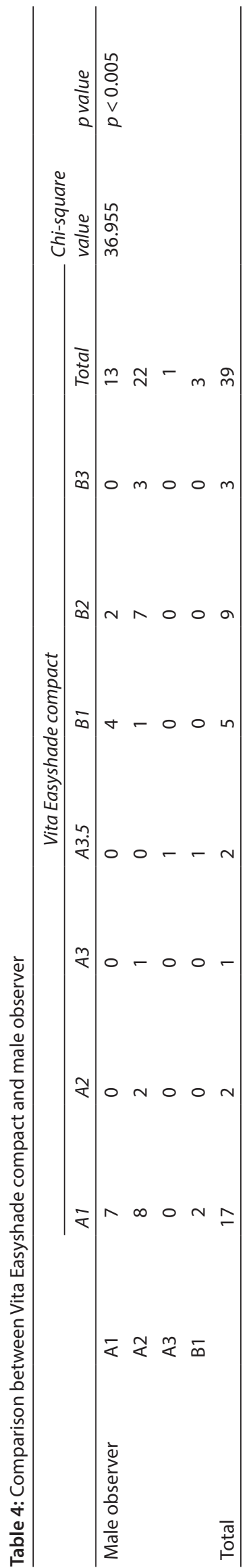




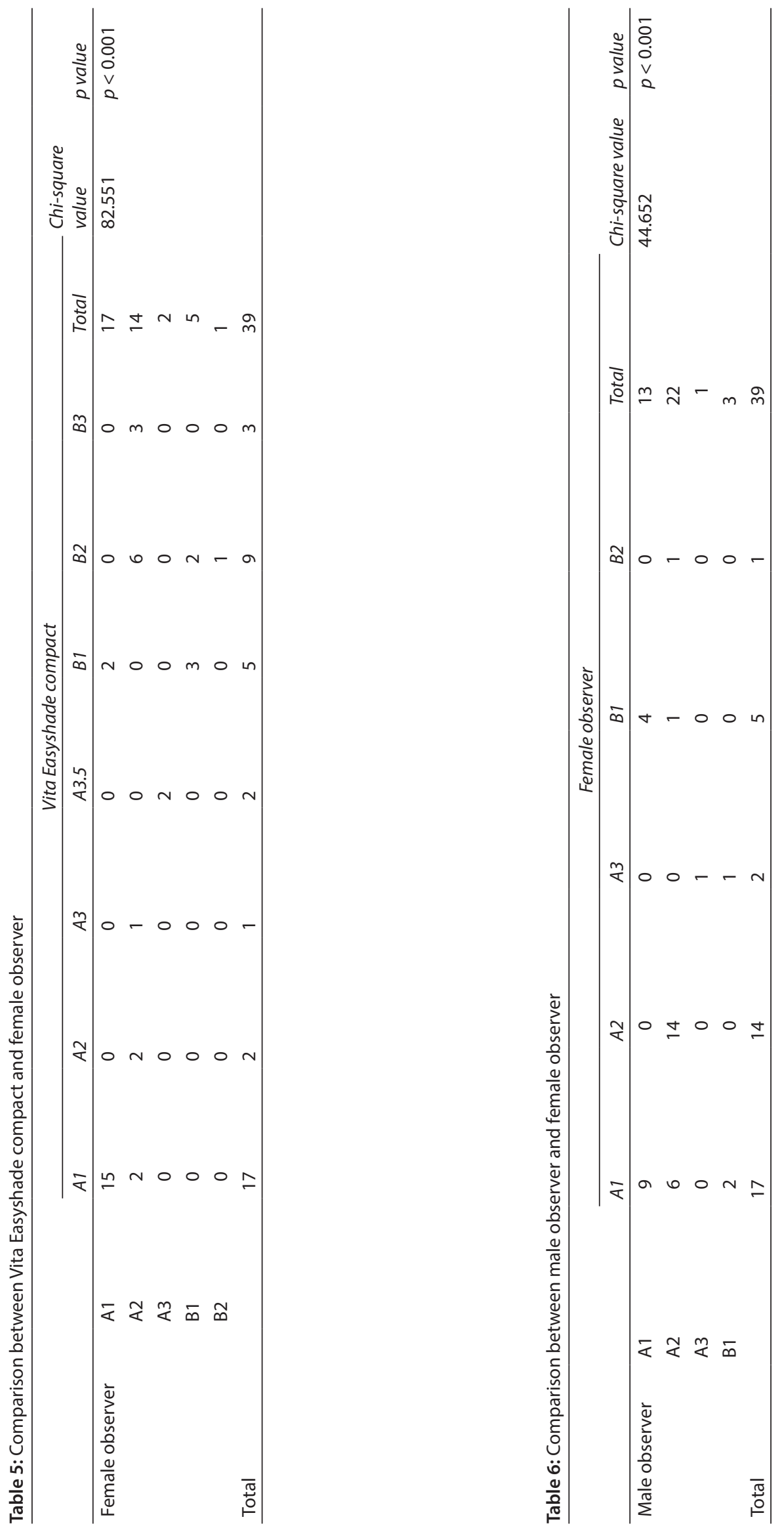


study found that 8 categories, grouped by 16 shades, improved agreement among examiners and hence, lends credence to Sproull's observations. ${ }^{19}$

In the present study, the observer used Rite-Lite to maintain standard light protocol with a correlated color temperature of $5,500^{\circ} \mathrm{K}$. Overall results show that there are significant $(p<0.005)$ differences between shade selected by female and male observers compare to digital shade matching devices.

\section{CONCLUSION}

The present study showed that female observers have better accuracy on visual shade selection under standard light illumination than a male observer in comparison with Vita Easyshade compact as shade selected by a female observer using Vita classic shade guide is closely matched with Vita Easyshade compact. But when the given shade guide and patient's teeth are to be matched, no cause exists, for the clinicians to be selected based on their gender. Better color vision screening should be performed for the clinician.

\section{References}

1. Allen W. Without feathers. Ballantine Books; 1975. p. 4.

2. Singh RK, Nidawani P, Galagali G, et al. Comparison of two commercially available shade guide under three different light condition with digital shade matching system: an in vivo study. Int J Dent Sci Inno Res 2019;2(4):496-505.

3. Borse S, Chaware SH. Tooth shade analysis and selection in prosthodontics: asystematic review and meta-analysis. J Ind Prosth Soc 2020;20(2):131-140. DOI: 10.4103/jips.jips_399_19.

4. Brewer JD, Wee A, Seghi R. Advances in color matching. Dent Clin North Am 2004;48(2):341-358. DOI: 10.1016/j.cden.2004.01.004.

5. Seal M, Talukdar P, Srivastav V, et al. Color atching: a review of conventional and contemporary dental color matching systems. IJOCR 2014;2(5):47-53.
6. Applebury ML, Hargrave PA. Molecular biology of the visual pigments. Vision Res 1987;26(12):1881-1895. DOI: 10.1016/0042-6989(86) 90115-X.

7. Joiner A. Tooth colour: a review of the literature. J Dent 2004;32:3-12. DOI: 10.1016/j.jdent.2003.10.013.

8. Haddad $\mathrm{H}$, Jakstat $\mathrm{H}$, Arnetzl $\mathrm{G}$, et al. Does gender and experience influence shade matching quality? J Dent 2009;37:40-44. DOI: 10.1016/j.jdent.2009.05.012.

9. Donahue J, Goodkind R, Schwabacher W, et al. Shade color discrimination by man and woman. J Prosthet Dent 1991;65(5):699703. DOI: 10.1016/0022-3913(91)90209-f.

10. Paravina RD. Evaluation of a newly developed visual shade matching apparatus. Int J Prosthodont 2002;15(6):528-534.

11. Jasinevicius TR, Curd FM, Schilling L, et al. Shade matching abilities of dental laboratory technicians using a commercial light source. J Prosthodont 2009;18(1):60-63.DOI: 10.1111/j.1532-849X.2008.00376.x.

12. Paravina RD, Ghinea R, Herrera LJ, et al. Color difference thresholds in dentistry. J Esthet Restor Dent 2015;27:1-9. DOI: 10.1111/jerd.12149.

13. Pecho OE, Ghinea R, Perez MM, et al. Lightness, chroma and hue differences on visual shade matching. Dent Mater 2016;32(11):13621373. DOI: 10.1016/j.dental.2016.08.218.

14. Barna GJ, Taylor JW, Kong GE, et al. The influence of selected light intensities on color perception within the color range of natural teeth. J Prosthet Dent 1981;46(4):450-453. DOI: 10.1016/00223913(81)90456-x

15. Moser JB, Wozniak WT, Naleway CA, et al. Color vision in dentistry: a survey. J Am Dent Assoc 1985;110(4):509-510. DOI: 10.14219/jada. archive.1985.0392.

16. Wyszecki G, Stiles WS. Color science. New York: John Wiley \& Sons; 1981. p. 25.

17. Rajan N, Krishna R, Rajan A, et al. Shade selection-basic for esthetic dentistry: literature review. Inter J Contemp Res Rev 2020;11(9):2086320868. DOI: 10.15520/ijcrr.v11i09.849.

18. Preston JD, Ward LE, Bodrick M. Lighting in the dental office. Dent Clin North Am 1978;22(3):431-451.

19. Sproull RC. Color matching in dentistry, part II. J Prosthet Dent 1973;29(5):556-566. DOI: 10.1016/0022-3913(73)90036-x. 